\title{
DIVESTMENT OF STATE-OWNED ENTERPRISES AND COMPETITION IN OIL \& GAS SECTORS IN VIETNAM
}

\author{
HA T. NGUYEN \\ Email : theha2911@gmail.com \\ UMUT TURKSEN \\ Centre for Financial and Corporate Integrity, Coventry University, UK \\ Email: umut.turksen@coventry.ac.uk
}

\begin{abstract}
In its endeavour to attract foreign investment inflows and realise the diversity and security of its energy supply, Vietnam has set out short, medium and long term strategies which have been articulated in a number of legal instruments. These developments include the drive and acceleration of divestment and liberalisation of the energy market and ensuring healthy competition therein. This article provides a critical analysis of the current divestment of state-owned enterprises (SOEs) in Vietnam's oil and gas sectors. In doing so, it also assesses current state of affairs against the key principles and objectives of competition law. After providing a brief summary of the milestones in the oil and gas sector, the article explains the equitisation in and privatization of SOEs and critiques the implications of these practices against the benchmarks of competition law provisions. After identifying the current problems and future challenges that lie ahead, it provides a number of constructive recommendations for policy development and legal reform.
\end{abstract}

Keywords: divestment, SOEs, competition, energy

\section{Introduction}

From the 1980s, onwards Vietnam pursued a central-subsidy economy in which the government planned and directly intervened in the market through state-owned enterprises ("SOEs") and administrative decisions. Accordingly, the Vietnamese economy was dominated by SOEs which enjoyed enormous privileges but were largely inefficient. The few competition rules that existed at the time in Vietnam were applied mainly to a minority of small private enterprises. There was, obviously, no room for the type of competition which is present in developed countries. ${ }^{1}$

The concept of market-based economy was addressed when the Vietnam Communist Party decided to carry out its Renovation ("Doi

OECD (2018), OECD Peer Reviews of Competition Law and Policy: Vietnam, p. 13, retrieved from

http://www.oecd.org/daf/competition/competition-law-and-policy-in-vietnam.htm [accessed 17 June 2019] 
Moi") policies to pursue the "socialist-oriented market economy"2 and to integrate with international trade through multilateral and bilateral trade agreements. One of the greatest changes in such economic policies was the recognition of variety of ownership of property and assets and economic sectors, i.e. Vietnamese government gradually adopted legal framework to create a more equal playing field for all economic players. In 2004, Vietnam adopted a comprehensive set of competition law provisions in connection with (but not required by) its accession process to the World Trade Organisation (WTO). ${ }^{3}$ The primary purpose of adopting competition law was to demonstrate to the world that Vietnam was committed to a marketbased economic system that is interconnected internationally. ${ }^{4}$

During this period, Vietnam also recognised the contribution of protrade (open market) and investment policies for boosting international trade and foreign direct investment ("FDI"). Particularly, the value of exports/ imports was US $\$ 21,500 / 22,800$ million while the FDI into Vietnam rose by 6.2 percent year-on-year to US $\$ 7.3$ billion in May 2019. ${ }^{5}$ Such progress and growth have been underpinned by key legal instruments, such as the 2005 Law on Investment ${ }^{6}$ (repealed by the 2014 Law), ${ }^{7}$ which aims to ensure greater transparency and predictability of administrative procedures. In addition, through these legal instruments, capital investment has been increased by attracting more sophisticated investors, and the legal regime and remedies for resolving disputes among investors have been put in place.

As a result, the 2018 Global Competitiveness Index (GCI) ranked Vietnam as 77, jumping 21 places since $2016 .{ }^{8}$ All of these developments have had direct relevance for, and impact on, investment and competition in the energy (oil and gas/ petroleum) sector.

Resolution No. 21/NQ-TW dated 30 January 2008 of the Communist Party defined that 'Vietnam's socialist-oriented market economy is an economic model, which both conforms to principles of the market economy, and is based on and guided by principles and nature of socialism in terms of the ownership, management organization and distribution. It comprises of many ownership types and economic sectors, in which the State-owned economy plays the vital role'. See also Resolution of the VI CPV National Congress (1987), National Political Publishing House, p. 86; Resolution of the VIII CPV National Congress (1996), National Political Publishing House, p. 72, 113; Resolution of the IX CPV National Congress (2001), National Political Publishing House, p. 86-88; Resolution of the XII (2016) CPV National Congress, retrieved from CPV Portal http://tulieuvankien.dangcongsan. vn/ban-chap-hanh-trung-uong-dang/dai-hoi-dang/lan-thu-xii/dai-hoi-dai-bieu-toan-quoclan-thu-xii-cua-dang-cong-san-viet-nam-3 [accessed 28 June 2019].

3 The Law on Competition No. 27/2004/QH11 (2004), repealed by the Competition Law No. 23/2018/QH14 (2018).

OECD (n 1)

Trading Economics, Vietnam-Economic Indicators (2019), retrieved from https://tradingeconomics. com/vietnam/indicators [accessed 17 June 2019].

The Law on Investment No. 59/2005/QH11 (2005)

The Law on Investment No. 67/2014/QH13 (2014)

Trading Economics, Vietnam Competitiveness Rank, retrieved from https://tradingeconomics. com/vietnam/competitiveness-rank [accessed 17 June 2019]. 
Over the past 40 years since the Vietnamese Government and Italian contractor, AGIP, signed the first production sharing contract in 1978, FDI in the oil and gas sector has not only brought large revenues to the country but also laid important foundation for development of the energy sector. By November 2015, there were 105 oil and gas exploration and production contracts with foreign partners, amounting to more than US $\$ 45$ billion in petroleum exploration and exploitation activities. ${ }^{9}$ Many large projects in the fields of gas, electricity, refining and petrochemical, and technical services have been brought on-stream to enhance development of the national economy and the industrialisation and modernisation of the country. ${ }^{10}$ In turn, actual and needed foreign investment flows have paved the need of a level playing field, increased the efficiency and competitiveness among key players. ${ }^{11}$

The second reform was restructuring of the SOEs for better efficiency and competitiveness. Apart from reorganising and incentivising those companies to follow the capital market rules, reforming of their ownership structure was also crucial. Without addressing this issue, the motivation for the SOEs to become more transparent, productive and competitive would have been significantly constrained. ${ }^{12}$ Against this backdrop, the government embarked on a plan in the early 1990s to equitise SOEs through four major phases: the $1992-1996$ Pilot stage, the $1996-1998$ expansion of Pilot programme, the $1998-2002$ acceleration of 'equitisation'13, and the continuing process currently. Over the last two decades, SOEs restructuring has been a key component of Vietnam economic reforms; nevertheless, it remains largely a work in progress. ${ }^{14}$

In August 2017, the government announced its ambitious plan to divestment 406 SOEs during the period of 2017-2020, comprised of many giants in key economic sectors such as agriculture, telecommunication, transportation, energy. ${ }^{15}$ In tandem with the above decision, Mr. Vuong

$9 \quad$ VietnamNet (2018), 'FDI lays foundation for acceleration of oil and gas sector', 4 October 2018, retrieved from https://english.vietnamnet.vn/fms/business/209633/fdi-lays-foundation-foracceleration-of-oil-and-gas-sector.html [accessed 21 April 2019].

10 Le, V.T, Pham, V.C. (2016), Overview of Vietnam oil and gas industry, 10 May 2016, retrieved from http://www.pvn.vn/Pages/detail.aspx?NewsID=f2a87c29-8c5e-4501-b203-7cdfb2b80976 [accessed 21 April 2019].

11 Nguyen, V.T, Ogunlana, S.O. \& Dey, P.K. (2007), "Risk management in oil and gas construction projects in Vietnam", International Journal of Energy Sector Management, vol. 1 issue: 2, pp. 175-194, p.176, retrieved from https://doi.org/10.1108/17506220710761582 [accessed 21 April 2019]. Le, H.H. (2017), "Vietnam's New Wave of SOE Equitization: Drivers and Implications", ISEAS Perspective, issue 2017, no. 57, p. 2, retrieved from https://www.iseas.edu.sg/images/ pdf/ISEAS_Perspective_2017_57.pdf [accessed 21 April 2019].

13 Equitisation, in Vietnamese 'Có phần hóa', is a Vietnamese English term that denotes the conversion of a state-owned enterprise in Vietnam into a public (joint stock) company or a corporation. It means the same as privatisation in its usage in Vietnam.

14 Le, H.H. (n 12).

15 Decision No. 1232/QD-TTg of Prime Minister (2017) giving approval for list of SOEs undergoing divestment in the 2017-2020 period. 
Dinh Hue - the Deputy Prime Minister - signed the Document No. 1182/ TTg-DMDN dated 11 August 2017 approving the list of Vietnam Oil and Gas Group (PetroVietnam - "PVN")'s subsidiaries to be equitised. As a result, the initial public offerings (IPOs) of three key energy companies, PetroVietnam Oil Corporation (PVOil), PetroVietnam Power Corporation (PVPower) and Binh Son Refinery Company (BSR) have been successfully launched in the first quarter of $2018 .{ }^{16}$

The envisaged benefits are that the State budget could overcome the fiscal deficit whereby public debt was very close to the permitted debt ceiling, comprised of inefficient use of public debts and shrinking room for fiscal policy. In the long term, the State needs to continually implement the SOEs restructuring, accelerate divestment of non-core businesses and focus on priority areas to address the pressing socio-economic issues. ${ }^{17}$

Given that the energy sector is top priority for economic growth and national security in Vietnam, there is no doubt that the role of two State-owned giants, Vietnam National Oil and Gas Group ("PVN") and the Vietnam National Petroleum Group ("Petrolimex") in terms of yearly State budget contribution and high ratio in Vietnam exported goods are important. Their businesses separately accounted for overall 16-18 percent of GDP while other State-owned enterprises (excluding the oil and gas industry) contributed about 42 percent of GDP. ${ }^{18}$ By holding stakes of such enterprises, the State is able to secure socio-political objectives, i.e. vary from ensuring national energy security, contributing to developing an independent and self-reliant economy to adequately supplying high-quality energy, developing an energy market which is conducive to fair competition and environmental protection. ${ }^{19}$

However, this sector has faced many tough challenges. Firstly, the depletion of natural resources of its main oilfields has put the PVN under great pressure to reach its oil exploration and production targets for 2018 and thereafter. Secondly, financing and access to credit from international institutions are getting harder while calling for foreign investments in large projects is likely to expose Vietnam to investment-related risks and disputes. Thirdly, the tariff elimination and "brain drain" of highly skilled labour

$16 \quad$ Reuteur (2018), 'PetroVietnam to raise more than US $\$ 570$ million from three IPO subsidiaries in January 2018', 15 January 2018, retrieved from https://www.reuters.com/brandfeatures/venturecapital/article?id=25134 [accessed 17 June 2019].

17 Nhan Dan Newspaper (2019), 'Vietnam accelerates divestment from State-owned enterprises', 8 January 2018, retrieved from http://en.nhandan.org.vn/business/item/5756902-vietnamaccelerates-divestment-from-state-owned-enterprises.html [accessed 21 April 2019].

18 Le, V.T et al. (n 10).

19 VietnamNews (2019), 'Tough challenges for oil, gas sector', 27 September 2017, retrieved from http://vietnamnews.vn/economy/394510/tough-challenges-foreseen-for-oil-gas-sector. html [accessed 21 April 2019] 
have become burdensome when the international trade and investment arrangements (e.g. WTO's covered agreements) where Vietnam is one of member states came into effect. ${ }^{20}$ One of the targets of such oil and gas SOEs equitisation is thus to increase market competition while it is generally accepted that competition fostered by government's policy is the driving force to enhance efficiency, quality, innovation and competitiveness of Vietnamese business players regionally and internationally. ${ }^{21}$

Regarding the above issues, the question on the relationship between privatisation process (SOEs divestment to pave the way for non-State economic sector's engagement) and competition policy to enhance the economic efficiency in the government's policy mix becomes crucial. Government's key objectives would ultimately determine relationship between these two instruments. A rent-seeking policy that wants to extract rent from businesses chooses not to privatise profitable SOEs but put the excessive costs on private firms. A market-friendly government on the other hand, aims at levelling the playing fields between both public and private entities. ${ }^{22}$

In order to form a reasoned opinion and conclude on the future prospects of these recent initiatives, this paper summarises the progress of SOEs divestment and the engagement of foreign companies in Vietnam's oil and gas industry. Next, it critically assesses the level of competition on to-be-equitised enterprises, particularly in the petrol retail market. Finally, it offers a number of recommendations for achieving the intended aims and creating a competitive energy market.

\section{Equitisation ${ }^{23}$ in SOEs and engagement of foreign investment in Vietnam's oil \& gas sector}

\subsection{The driving forces of the privatisation process}

Foremost, the oil and gas sector is the top priority for economic growth and energy security where Vietnam has enormous potential for large

$20 \quad$ Ibid.

21 Singh, A. (2002), Competition and Competition Policy in Emerging Markets: International and Developmental Dimensions, UNCTAD G-24 Discussion Paper Series no. 18, September 2002, p.7, retrieved from http://unctad.org/en/docs/gdsmdpbg2418_en.pdf [accessed 21 April 2019].

22 Vu, T.T.A. (2006), "Competition and Privatisation in Vietnam: Substitutes or Complements?", Paper presented at the Conference of the Japanese National Graduate Institute for Policy Studies Tokyo, Japan, 15 July 2006, http://www.grips.ac.jp/vietnam/VDFTokyo/ Doc/2ndConf15Jul06/2EcoSession2VTTAnh.pdf.

23 Le, H.H. (n 12), pp.2-3: In all the official documents, the process is referred to as "cổ phân hóa (equitization)" rather than "tư nhân hóa (privatization)". From the CPV's perspective, "equitization" is a more precise term as the state normally retains a large stake in most of the equitized SOEs, and only a limited amount of their shares are sold to private investors. Moreover, the term "equitization" carries a less negative ideological overtone. As the CPV still considers the state-owned sector the backbone of the "socialist-oriented market economy" that it strives for, the term "privatization" implies a deviation from its goal. Nevertheless, "equitization" and "privatization" are not clearly different in practical terms. Many non-essential SOEs have been wholly privatized, and the Vietnamese government has also reduced or completely divested its stakes in many equitized SOEs, effectively turning these firms into private entities. 
reserves. The extraction of petroleum resources have commenced three decades ago and Vietnam has substantially increased its overall production, with the accumulative 346 million tonnes of crude oil and 108 billion cubic meter of natural gas. ${ }^{24}$ In tandem with the exploration and production activities, the country has paid great attention to the development of refinery and processing facilities for achieving the goals of national energy security (security of supply) as well as adequate and high-quality supply for economic growth. ${ }^{25}$ By 2007, the National Energy Development Strategy 2020, with an outlook to 2050, was approved by the Prime Minister, which set out several ambitious goals, inter alia the construction of oil refineries to rise the total capacity to 25-30 million tonnes of petrol and petrochemical products by 2020 in order to meet the domestic demand and pursue to export. ${ }^{26}$

Despite positive outlooks, the oil and gas industry has been facing tough challenges. Firstly, under the above development strategy towards 2025 , this sector aims to annually increase oil and gas reserves to 35-40 million tonnes of oil equivalent (MTOE), increase oil and gas exploitation by 10-36 percent for each five-year period, compared to the current levels (approximately 24 million tonnes of crude oil in 2018). ${ }^{27}$ However, over more than 30 years, the major oil fields in Vietnam are in depleting phase that has put the PVN under great pressure to reach its oil exploration and production targets for 2018 and thereafter. ${ }^{28}$

Secondly, in terms of oil and gas projects, these are generally exposed to both internal risks and external risks. The internal risks are often related to financing, ${ }^{29}$ design, contractual, construction, involved parties and operational issues while the external risks generally emanate from security - political -

$24 \quad$ PVN, 'Exploration and Production' (Hoạt động Khai thác Dầu khí), retrieved from http:// www.pvn.vn/Pages/detailv4.aspx?NewsID=5e1ae9ea-1ec3-4704-83e4-9b7614d04cee [accessed 21 April 2019].

25 Cong Thuong Newspaper (2016), 'Vietnam Energy Forum 2016: Challenges for Sustainable Development', 25 August 2016, retrieved from https://congthuong.vn/dien-dan-nang-luongviet-nam-2016-thach-thuc-cho-phat-trien-ben-vung-74115.html [accessed 17 June 2019].

26 Decision No. 1855/QD-TTg of Prime Minister on Approving Vietnam's National Energy Development Strategy up to 2020, with the Outlook to 2050 (2007), Art.1.2, sub-section b), para.4.

27 Nang Luong Journal (2019), 'Achievements of PVN in 2018' (Những dấu ấn nổi bật của PVN trong năm 2018), 14 January 2019, retrieved from http://nangluongvietnam.vn/news/vn/dau-khi-vietnam/nhung-dau-an-noi-bat-cua-pvn-trong-nam-2018.html [accessed 22 June 22, 2019].

28 Nguyen, H.T (2018), "Enhanced oil recovery in Vietnam: Potential and Opportunities", PetroVietnam Journal, vol 6/2018, p. 83, retrieved from http://www.pvn.vn/DataStore/ Documents/2018/TapChiDauKhi/TCDK_6_2018.pdf [accessed 22 June 22, 2019].

29 Different financing models may be employed in energy projects; government financing, corporate financing, hybrid financing, project finance. Each brings with its different requirements and risk factors. While it is beyond the scope of this article to examine each model, some of the modernday financing methods are proposed as follows: Government-to-Government Financing, Loan Guarantee, Host Government-Backed Power Purchase Agreement (PPA), Vendor Financing, and Investor Financing. For detailed analysis see, Terlikowski P. et al. (2019), "Modern financial models of nuclear power plants", Progress in Nuclear Energy, vol 110, pp. 30-33. 
legal status of host country, risks on economy, market conditions during the project operation, concerns over environmental and social impacts of such projects in certain geographical areas and on residents. Therefore, financing and access to credit from international institutions are getting harder while calling for foreign investments in large projects is likely to expose Vietnam to investment-related risks and disputes. ${ }^{30}$

Third, under the free trade agreements and commitments that Vietnam has signed, import tariffs on petroleum products would be zeroed out, affecting the domestic oil and gas industry. Particularly, the tariff rate for imported petrol from all WTO members (under the Most-Favoured Nation treatment) is 40\%; however, the ASEAN Agreement in Goods (ATIGA) schedule has provided that such rate would be reduced to $20 \%$ since 2012 , and to $0 \%$ by $2016 .{ }^{31}$ The Vietnam-Korean Free Trade Agreement has also ruled the preferred tariff applied for imported petrol would be $10 \%$ to $0 \%$ between 2016 and 2018. ${ }^{32}$

With the establishment of the ASEAN Economic Community (AEC), in addition to the tariff reduction, there would be a shift in the labour force within the industry, leading to "brain drain" for the sector. For example, some of PVN's highly-skilled workers might move to other oil companies in ASEAN countries if they could offer better working conditions. The whole industry therefore needs to adjust and put forward a strategy so that it could compete with competitors locally and internationally. ${ }^{33}$

Vietnam exercises its ownership over the natural resources and confers the management of these to the national oil companies. Accordingly, the Petroleum law provides that:

"The Vietnam Oil and Gas Corporation (known in its international dealings as Petrovietnam) is a State-owned enterprise established by the Government of Vietnam to conduct petroleum operations and enter into petroleum contracts with organizations and individuals for the conduct of petroleum operations in accordance with this Law." ${ }^{34}$

The company's core businesses are comprised of entering into petroleum contracts with other entities, managing and supervising the exploitation, production of petroleum resources on the ground of such contracts. ${ }^{35}$ Particularly, it is mandated to allocate acreage by tendering

Nguyen, V.T. et al. (n 11)

31 The ASEAN Trade in Goods Agreement (ATIGA), Annex 2 - Tariff Schedule of Vietnam, Schedule A, section 2705.

32 The Vietnam-Korea Free Trade Agreement (VKFTA), Chapter 2 - National Treatment and Market Access for Goods, Annex 2-A - Tariff Schedule of Vietnam, Schedule A, section 2710.

33 VietnamNews (n 19).

34 The Petroleum Law No. 18-L/CTN (1993), amended by Law No. 19/2000/QH10 (2000) and Law No. 10/2008/QH12 (2008), Art.14.

35 Decree 149/2013/ND-CP (2013), Art. 3.3. 
or direct negotiation with selected licensees or participate in the Joint Ventures, and act as the technical liaison with those licensees. ${ }^{36}$ It is virtually a business entity that refers to a player in revenue-generating activities, ${ }^{37}$ yet the national oil company is also a mean for conducting the State's noncommercial duties which vary from ensuring national energy security, contributing to developing an independent and self-reliant economy to adequately supplying high-quality energy, developing an energy market which is conducive to fair competition and environmental protection. ${ }^{38}$ The importance of the energy sector often leads to direct intervention from the State based on political rather than an economic arguments and rationale thus resulting in substantial costs. ${ }^{39}$

The PVN's report to the Ministry of Industry and Trade (MOIT) revealed that the company has suffered from substandard operation including lack of effective coordination and cooperation among its departments. In comparison with other national oil companies in ASEAN region, PVN's productivity only accounted by $10-50$ percent of those in Petronas (Malaysia) and PTT (Thailand). ${ }^{40}$

Furthermore, the company has faced the "principal-agent problem" between governmental authorities (representative of Vietnamese nationals the ultimate owners over the natural resources) and the board of directors. Endowing PVN with large non-commercial functions and powers could lead to take advantage of its positions in these realms and advance its own interests, which are not always be fully consistent with those of the country. In the worst scenario, conferring authority for allocation of exploration and production rights to the PVN can open a door for corruption. ${ }^{41}$ For example, unlawful acts of PVN's and its subsidiaries' board of management during 2006-2011 period were alleged, including the case of PetroVietnam

$\overline{36}$ Decree No. 149/2013/ND-CP on Charter of National Oil and Gas Group (PetroVietnam) (2013), Art. 3 of the Charter; Decree No. 95/2015/ND-CP detailing provisions of the Petroleum Law (2015).

37 Decision No. 199/2006/QD-TTg of the Prime Minister (2006) provided that: 'PetroVietnam has its major functions and responsibilities following: b) Perform petroleum activities and enter into petroleum contracts with organizations, individuals who conduct the petroleum operation; [...] c) Directly produce, do business in respect to commercial purposes in accordance with the laws [...]'.

38 Decision No. 1855/QD-TTg of the Prime Minister (2007), Art. 1.2(a).

39 Tordo, S., Tracy, B.S, Arfaa, N. (2011), National Oil Companies and Value Creation, World Bank Working Paper no. 218, p.25.

40 Nguyen Hai (2018), 'PVN's comprehensive reform' (PVN ‘đại cải tổ' sau hàng loạt lãnh đạo vướng vòng lao lý), Tuoitre Newspaper, 16 April 2018, retrieved from https://tuoitre.vn/pvndai-cai-to-sau-hang-loat-lanh-dao-vuong-vong-lao-ly-20180416073621657.htm [accessed 23 June 2019].

41 Heller, P.R.P., Mahdavi, P. \& Schreuder, J. (2014), Reforming National Oil Companies: Nine Recommendations, Natural Resource Governance Institute, p.8, retrieved from https:// resourcegovernance.org/sites/default/files/documents/nrgi_9recs_eng_v3.pdf [accessed 21 April 2019]. 
Financial Corporation (PVFC), ${ }^{42}$ the VND800 billion-loss (approximately US \$94 million) of PetroVietnam Construction Corporation (PVC) pouring into the OceanBank, ${ }^{43}$ and a ineffective key project, Dinh Vu poly-fiber plant are three bio-ethanol projects. ${ }^{44}$

It is also worth noting that Vietnamese energy projects are often procured for foreign multinational oil companies because of the limited supply of capital and technological know-how nationally. Within the 1988 - 2014 period, more than 40 international oil companies from the United States, Japan, Russia, United Kingdom, Malaysia, France, Spain, Canada, and Australia have invested in both upstream projects and downstream processing facilities through various types of contracts. While bringing capital and modern technology to Vietnam, they have fostered the need for market reform to create a level playing field and to facilitate the increased engagement of private enterprises in the energy sector. ${ }^{45}$

These above facts however do not represent the whole picture of the Vietnam economy. The steady erosion in the productivity may be driven by two main factors: the institutional foundations for an advanced market economy are insufficiently developed, undermining private property rights; and competition in product markets where market factors are allocated and driven by fiat. Commercialized state institutions - whereby the State is directly involved in economic activities and indirectly involved through the influence of vested interests - have ensured that economic resources allocations are guided as much by arbitrary administrative decisions as by efficient market signals. ${ }^{46}$

Furthermore, Vietnam is experiencing new and emerging fiscal challenges, including narrower fiscal space, rising public debt and concerns about the medium-term sustainability of the current fiscal position. State revenue sources, particularly from tax and fees, have decreased, whilst spending on public services has increased and it needs to be continued to grow. Therefore, in order to ensure fiscal sustainability, concerted efforts to boost revenue mobilisation, restructuring and enhancement of efficiency in spending, and strengthening the management of public assets and liabilities,

42 Thanh Nien Newspaper (2017), 'PVFC's inefficiency', 18 March 2017, retrieved from https:// thanhnien.vn/thoi-su/tai-chinh-dau-khi-va-vung-lay-pvn-815718.html [accessed 23 June 2019].

43 VNExpress Newspaper (2017), 'Vietnam reopens massive bank fraud trial', 28 August 2017, retrieved from https://e.vnexpress.net/news/news/51-bankers-businessmen-in-the-dock-asvietnam-reopens-massive-bank-fraud-trial-3633651.html [accessed 23 June 2019].

44 Tuoitre Newspaper (2018), 'PVN suggests the bailouts for 12 mass projects' (PVN muốn chi tiền giải cứu các đại dự án thua lỗ ngàn tỉ), 26 February 2018, retrieved from https://tuoitre. vn/pvn-muon-chi-tien-giai-cuu-cac-dai-du-an-thua-lo-ngan-ti-20180226180905857.htm [accessed 23 June 2019].

$45 \quad$ Nguyen, V.T et al. (n 11).

46 World Bank Group \& Vietnam Ministry of Planning and Investment (2016), The 2035 Vietnam Report: Toward Prosperity, Creativity, Equity, and Democracy, p. xxvi. 
and of fiscal risks are needed. ${ }^{47}$ The divestment in non-core business SOEs could be one of such mechanisms which may help to balance the State budget and raise funds for other infrastructure investments in the short term.

Given the above scenarios, the reform of state-owned businesses is necessary and irreversible. Accordingly, the PVN should focus on its core business activities, i.e. oil and gas exploration and production, gas industry, power industry, petroleum processing. In addition, it should accelerate the restructuring of its subsidiaries and affiliates in line with the 2016-2020 development strategic plan. ${ }^{48}$ In tandem with the reform of the PVN, the market access initiatives in the petroleum sector should continue to open for non-state businesses through the specific incentives granted to investors in key energy projects that create the pressure on domestic rivals to upgrade the market competition, improve the quality of their goods and services, and enhance the consumer relations and marketing activities. ${ }^{49}$ Such initiatives ought to also take into account renewable energy investment and products as reliance on oil and gas does not offer the diversity and sustainable energy supply mix which Vietnam needs.

\subsection{An overview of the privatisation in petroleum sector}

\subsubsection{The new wave of energy SOEs equitisation}

The main aim of a government in a socialist-oriented market economy is ascertained by maintaining the stronghold of SOEs power in many key sectors, and utilising such power to support the political goals. ${ }^{50}$ From this point of view, the Vietnamese government has classified all SOEs into three categories in the light of their political and economic roles and devised different ownership and control structures therein:

The first group is comprised of enterprises that are strategically essential and should therefore be put under total State ownership and control. Particularly, according to the Official Document No. 1182/TTg-DMDN, the State determines to maintain the whole ownership of PVN - holding (parent) company, and keeps this enterprise under the form of a one-member limited liability company.

$\overline{47 \quad \text { Tran, K.C. \& }}$ Djalal, D. (2017), 'The World Bank and Vietnam Work to Strengthen Fiscal Policies and Management Towards Sustainability, Efficiency, and Equity', Press Release, 3 October 2017, retrieved from http://www.worldbank.org/en/news/pressrelease/2017/10/03/the-world-bank-and-vietnam-work-to-strengthen-fiscal-policies-andmanagement-towards-sustainability-efficiency-and-equity [accessed 22 June 2019].

48 Ngoc Phuong (2017), 'PetroVietnam: Focus on restructuring and boosting production', PetroVietnam Journal vol. 6/2017, p.12, retrieved from http://www.pvn.vn/DataStore/ Documents/2017/Tapchi\%20Dau\%20khi/TCDK\%2007\%202017.pdf [accessed 22 June 2019].

49 Tuoitre Newspaper (2017), 'Vietnam's fuel fight heats up as market welcomes first foreign player', 12 October 2017 2017, retrieved from https://tuoitrenews.vn/news/society/20171012/ vietnams-fuel-fight-heats-up-as-market-welcomes-first-foreign-player/42018.html [accessed 22 June 2019].

$50 \quad$ Vu, T.T.A. (n 22), p.5. 
The second group includes SOEs for which the government wishes to retain significant control by holding the majority of shares; for example, over 75 percent, from 65 to 75 percent, or from 50 to 65 percent of corporate capital after the partial divestment to private investors. ${ }^{51}$ There includes enterprises working on oil and gas exploitation and production, petroleum processing, wholesaling and distribution. ${ }^{52}$

The third group consists of the remaining SOEs which could be privatised under various means, such as issuing new shares, selling a fraction of existing shares held by the State, equitising enterprises to become corporations and selling off all State assets to employees, private shareholders and other stakeholders..$^{53}$

Accordingly, the Decision No. 58/2016/QD-TTg dated 28 December 2016 of the Prime Minister on criteria for classification of wholly SOEs, partially SOEs and list of SOEs undergoing restructuring in the 2016 2020 period (Decision 58) specifies certain PVN's subsidiaries are to have their State ownership reduced, including PetroVietnam Oil Corporation (PVOil), PetroVietnam Power Corporation (PVPower), Binh Son Refining and Petrochemical Company Limited, and Dung Quat Shipyard. It means that the majority of their shares shall be transferred to private sectors while the State will hold not more than 50 percent stake.

After the Decision 58 was issued, the first PVN unit launching an IPO was Binh Son Refining and Petrochemicals Company Limited (BSR) which operates Dung Quat Refinery with the book value on 31 December 2015 of over VND72 trillion (US $\$ 3.2$ billion). ${ }^{54}$ In the approved plan, the 49 percent stake shall be publicly offered and PVN will only keep the remaining 43 percent ownership..$^{55}$ Prior to the IPO launching, the Decision No. 1725/ QD-TTg of the Prime Minister has deregulated the crucial subsidies on its petroleum products consumed domestically since 1 January 2017 whereby BSR shall no longer retain the import duties and has to fulfil its tax obligations like other enterprises. This means that BSR's revenue would annually decrease by VND0.7 - 3.8 trillion (US $\$ 30.83$ - 167.34 million) and its products would

\footnotetext{
51 Appendix I - Criteria to classify SOEs, Enterprises having State's capital attached to the Decision No. 58/2016/QD-TTg (2016).

52 Allen \& Overy (2015), Publications: Vietnam lifts the cap on foreign ownership of public companies, 20 July 2015, retrieved from http://www.allenovery.com/publications/en-gb/Pages/Vietnamlifts-the-cap-on-foreign-ownership-of-public-companies.aspx [accessed 22 June 2019].

53 Le, T.A.N. (2015), State-owned Enterprise Reforms in the TPP Negotiation: Is it a win-win for Vietnam?, RIETI Discussion Paper Series 15-E-092, p.7, retrieved from https://www.rieti. go.jp/jp/publications/dp/15e092.pdf [accessed 22 June 2019].

54 The Decision No. 1938/QĐ-BCT of Ministry of Industry and Trade (2015).

55 BSR (2017), "IPO of BSR" (IPO Lọc hóa dầu Bình Sơn: Thị trường thêm hàng "khủng"), 16 June 2017, retrieved from https://bsr.com.vn/vi/ipo-loc-hoa-dau-binh-son-thi-truongthem-hang-khung.htm [accessed 22 June 2019].
} 
become uncompetitive on the local market. Moreover, the regulatory charge of 7\% is imposed on the country's first oil refinery to balance import tariffs on fuels and taxes on crude oil imported by the refinery. ${ }^{56}$

Surprisingly, without the fear of limited appeal in terms of its financial viability, the first batch of shares (nearly 250 million shares) were offered in January 2018 at the Ho Chi Minh Stock Exchange (HOSE), equivalent to 7.79 percent BSR's stake, and subsequently, over VND5.5 trillion worth of shares were sold. Three weeks later, thousands of investors, both domestic and international, have registered to buy out, and the final amount of sold stake reached approximately 650 million shares, over 2.7 times of the volume offered. ${ }^{57}$ The next plan is to seek the strategic partners who could offset the shortcomings on plant operation and support for the upgrade and expansion of petrochemicals and deep-processing facilities, which are expected for commercial operations in 2021 in accordance with the Euro 5 standard products. With respect to project financing, 30 percent of the capital (around US $\$ 1,269$ million) was derived from funds gained by the equitisation and profits of 2018, and the remaining capital would be derived from loans. The longer it takes to secure the capital arrangements, the more the delay in achieving intended economic efficiency and quality. As Dung Quat Refinery's petroleum products are classified as under Euro 2 Standard, they would not be qualified for domestic consumption which forces the plant to reduce its production or even stop its operation completely. ${ }^{58}$

The second entity to undergo an IPO is PetroVietnam Oil Corporation (PVOil), a unit of PVN which exclusively takes part in the development of the downstream activities, including crude oil import and export, trading and processing, storage and distribution. Over the last 30 years, PVOil has already sold around 300 million metric tonnes of crude oil produced in Vietnam and overseas, and supplied in exclusive crude oil feedstock to Dung Quat refinery at an average quantity of 7 million metric tonnes per year. ${ }^{59}$

The company is scheduled to sell up to 51 percent stake where the strategic shareholders are expected to account for 39 to 44 percent. ${ }^{60}$ As a

\footnotetext{
$56 \quad$ SaigonTimes (2019), 'Quang Ngai proposes solutions to Dung Quat refinery difficulties', 27 December 2017, retrieved from https://english.thesaigontimes.vn/57736/Quang-Ngaiproposes-solutions-to-Dung-Quat-refinery-difficulties.html [accessed 22 June 2019].

57 BSR (2018), 'Successful IPO with 242 million BSR's stakes is sold' (IPO thành công 242 triệu cổ phần Lọc hóa dầu Bình Sơn), 17 January 2018, retrieved from https://bsr.com.vn/en/ipothanh-cong-242-trieu-co-phan-loc-hoa-dau-binh-son.htm [accessed 22 June 2019].

58 VietnamNews (2017), 'Dung Quat oil refinery works on expansion project', 24 July 2017, retrieved from http://vietnamnews.vn/economy/380693/dung-quat-oil-refinery-works-onexpansion-project.html\#P8MMZMq6ruDmGJJi.99 [accessed 22 June 2019].

59 PVOil (2019), Business Activities, retrieved from https://www.pvoil.com.vn/en-US/businessactivities [accessed 22 June 2019].

60 The Decision No. 1979/QD-TTg approving equitization plan of PetroVietnam Oil Corporation (2017), Art.4 and Art. 5.
} 
result, the IPO sale was opened in January 2018, where nearly 207 million shares with the value over VND2,770 billion - accounting for 20 percent of charter capital of the company have been acquired by a variety of investors. Beyond all expectations, the subsequent registered volume to buy was more than 483 million shares, 2.33 times of the volume offered to be exact. PVOil then applied to be listed in the stock exchange market (the Unlisted Public Company Market - UPCoM) under the relevant regulations. ${ }^{61}$

The third and the final company up for sale is the PetroVietnam Power Corporation (PVPower), the country's second-largest electricity producer after Electricity of Vietnam (EVN), with 12 percent of market share. According to the final structure approved by the government, the State will retain a 51 percent stake, and offer 28.9 percent to strategic investors and another 20 percent in the public equity market. ${ }^{62}$ At the ceremony held in Hanoi Stock Exchange, this was hailed as the biggest deal on traded value, about VND7 trillion (US\$308.1 million), with the participation of nearly 2,000 purchasers (97 institutional investors and nearly 1,900 individuals). ${ }^{63}$

In sum, there are three success stories in relation to the equitisation of Vietnam's SOEs within the first quarter of the strategic schedule of 2018 2020. It could be expected that the progress of equitisation of energy SOEs will continue, with the future deals of PVGas, which has generated over 30 percent of PVN's annual profits ${ }^{64}$ and a dozen of other PVN's subsidiaries are expected to be offered for sale. ${ }^{65}$

\subsubsection{Increasing the engagement of foreign investment in energy projects}

Apart from participating in exploration and production projects over the years, foreign investment is paying attention to development on key downstream facilities. By upgrading the refinery capacity, Vietnam has not only ensured the sufficient and clean fuel supply for domestic consumption and minimising dependence on imported energy supplies, but also has been able to export petrochemical products. ${ }^{66}$ Due to the lack of financial

61 Vietnam Investment Review (2018), 'PV Oil collects $\$ 190$ million from IPO', 30 January 2018, retrieved from https://www.vir.com.vn/pv-oil-collects-190-million-from-ipo-56010.html [accessed 22 June 2019].

62 The Decision No. 1977/QD-TTg of the Prime Minister approving equitization plan of PetroVietnam Power Corporation (2017).

63 VietnamNews (2018), 'PV Power raises $\$ 311$ million from IPO', 1 February 2018, retrieved from http://vietnamnews.vn/economy/422255/pv-power-raises-311-million-from-ipo. html\#f4gj3ycX7kvpZmae.97 [accessed 22 June 2019].

64 Vietnam News (2018), 'Government focuses on divestment in oil and gas sector', 26 February 2018, retrieved from https://vietnamnews.vn/economy/business-beat/423334/government-focuseson-divestment-in-oil-and-gas-sector.html\#yVcL5iRfAyKVJU9w.97 [accessed 22 June 2019]. Decision No.1232/QD-TTg of the Prime Minister Minister giving approval for list of SOEs undergoing divestment in the 2017-2020 period (2017).

66 Searle, S. \& Malins, C. (2016), Case study: refineries in Vietnam, The International Council on Clean Transportation (ICCT) Working Paper, vol. 2016-3, p.1. 
resources and technology know-how domestically, the positive role of FDI has been successfully demonstrated through three key projects in the refinery and petrochemical sectors.

Dung Quat refinery - the first oil refinery in Vietnam - has been in operation since 2009 , with the capacity of over 6.5 million tonnes of products per annum (mainly from diesel and gasoline that meet Euro 2 standards). ${ }^{67}$ During the project implementation, the joint venture between Vietnam and Russian partner (Vietnamese Russian Joint Venture Vietross Refinery) was dissolved because of the unreasonable capital structure (50/50) and the inefficient decision-making procedures, combined with the lack of experience on refinery and incompetent human resources. ${ }^{68}$

The adverse consequence was that the increased cost from initial US $\$ 1.3$ - 2.5 billion, nearly double of the budget approved by the National Assembly in 1997. Five out of six main work packages of the project fell behind the proposed schedule for at least six months. In August 2009, PetroVietnam temporarily halted its operations because of a broken valve in a fluid catalytic cracker for petrol products. Technip was chosen to fix the problem and to hand over the new refinery technology to PetroVietnam in May 2010. The refinery processed 4 million tonnes of crude oil and produced 3 million tonnes of petroleum products such as gasoline, diesel and fuel oil. An expansion project to increase its capacity to 10 million tonnes is being undertaken, which requires an investment of US\$1-2 billion. ${ }^{69}$

The second refinery, Nghi Son Integrated Refinery and Petrochemical (NSRP), was built in July 2013 and has been operated commercially since February 2018. NSRP is sponsored by four corporations: PVN, Kuwait Petroleum Europe B.V. (KPE) from Kuwait, Idemitsu Kosan Co., Ltd. and Mitsui Chemical, Inc. from Japan. This plant is the largest-ever FDI in Vietnam to date and therefore the success of this project is the key to attract further foreign investments into Vietnam, especially FDI from Japan and Kuwait. ${ }^{70}$

In February 2018, the construction of Long Son Petrochemicals (LSP), the third and a mega-petrochemical refinery complex, has been launched. This project is strategically important for Vietnam in order to meet the growing domestic demand for refined and petrochemical products driven by rapid industrialisation and modernisation of the country. After several

\footnotetext{
$67 \quad$ Ibid.

68 VNExpress Newspaper (2002), 'The withdrawal of Russian partner in Dung Quat Refinery', 20 November 2002, retrieved from https://vnexpress.net/kinh-doanh/doi-tac-nga-rut-khoilien-doanh-loc-dau-dung-quat-2671022.html [accessed 22 June 2019].

${ }^{69}$ HydroCarbons Technology, Dung Quat, Oil Refinery No.1 https://www.hydrocarbonstechnology.com/projects/dung/ accessed 22 June 2019.

70 NSRP (2019), 'Overview', retrieved from http://nsrp.vn/the-project/2_overview [accessed 22 June 2019].
} 
adjustments on shareholder and capital structures, the project might be wholly owned by the Thai industrial conglomerate Siam Cement Group (SCG), after the successful acquisition of PVN's assets. ${ }^{71}$

In short, there are two remarkable milestones during the privatisation in petroleum sector. Firstly, the SOEs divestment has been firmly accelerated by a strong will from the government. In return, the positive reception of domestic and foreign investors towards the IPO deals has shown the attractiveness of energy enterprises due to high expectation on business rewards and other interests. ${ }^{72}$ Secondly, the Vietnamese government has signed international treaties ${ }^{73}$ and enacted domestic legal instruments ${ }^{74}$ to honour and safeguard its obligations therein. These commitments have had a direct impact on the increased participation of foreign partners in key energy projects. In addition, they have led to the realisation that regulatory reforms are urgently needed to incentivise investment by international stakeholders and more importantly put in place a legal framework to ensure fair and equitable treatment of non-State entities operating in the energy sector.

In the next section, critical assessment of the impact on such privatisation on market competition and corporate performance is provided. In doing so, particular reference is made to petro retail market access which is granted to foreign entities.

\section{Impact of equitisation on completion: An initial assessment}

According to a study implemented by the Vietnam Petroleum Institute, the petrol demand in 2017 was over 19.3 million tonnes while the maximum annual capacity of the Dung Quat refinery - the only in-operation refinery in Vietnam at the time - was around 6.5 million tonnes, satisfying only a one-third of the market demand. The remaining portion had to be fulfilled by import, mainly from ASEAN countries and Korea. The quantity of

$71 \quad$ Tuoitre Newspaper (2018), 'Thailand partner offers to acquire the whole LSP' (Đại gia Thái muốn mua trọn Hóa dâu Long Sơn 5,4 tỉ US\$), 22 January 2018, retrieved from https://tuoitre.vn/daigia-thai-muon-mua-tron-hoa-dau-long-son-5-4-ti-US\$-20180122113955208.htm [accessed 22 June 2019].

72 Reuteur (n 16).

73 The CPTPP and VN-EU FTA also have the provisions to protect the legal rights and interest of foreign investors. For example, the draft of VN-EU FTA, Section III: SOEs, Art.4 - Nondiscrimination and commercial considerations: "1. Each Party shall ensure that its state-owned enterprises, designated monopolies and enterprises granted special rights or privileges, when engaging in commercial activities,: (...) b) accord to enterprises of the other Party, enterprises that are investments of investors of the other Party, goods of the other Party, and services of the other Party, treatment no less favourable than they accord to, respectively, enterprises of the Party which are in like situations, like goods of the Party, and like services of the Party, with respect to their purchases or sales of goods or services in the relevant market."

74 The Law on Competition (2004), Art.2 - Applicable entities: "This Law shall apply to: 1. Organizations and individuals conducting business (hereinafter together referred to as enterprises), including enterprises engaged in production or supply of public utility products or services, enterprises conducting business in State monopoly industries and sectors and overseas enterprises operating in Vietnam." 
imported petrol reached nearly 9 million tonnes in 2017 with the cost of US $\$ 4.5$ billion. In comparison with the same quarter in 2016 , there was a 10 percent increase in quantity, and 40 percent in value. ${ }^{75}$

Against this background, the government has emphasised the development of domestic refineries in order to achieve the goals of national energy security and adequate and high-quality supply for economic growth. ${ }^{76}$ The construction of the second and the third refinery and petrochemicals plants demonstrates determination of the State to achieve such goals set forth in the National Energy Development Strategy, inter alia increasing the annual domestic capacity up to $25-30$ million tonnes of petroleum products. ${ }^{77} \mathrm{Nghi}$ Son Integrated Refinery and Petrochemical which is "in-production" status, with the first batch of 5,000 tonnes of petrol in May 2018, is an optimistic signal; however, the needed productivity is far away in the short term. ${ }^{78}$

In its eagerness to attract investment, Vietnam has committed to several exceptional incentives, i.e. guarantee in the wholesale price of products from the plant, special tax reliefs and maintaining the duties applicable to imported petroleum products not less than 7 percent until 2028. ${ }^{79}$ Moreover, the foreign sponsors have been permitted to access in the petrol retail market which mainly aims to be distribution system of products manufactured by the plant. ${ }^{80}$

As a result, Idemitsu Q8 Petroleum owned by the consortium of Idemitsu Kosan and Kuwait Petroleum International (KPI) was established in April 2016 which launched the first filling station in Thang Long Industrial Park, Hanoi in October 2017. This event was an awakening for its Vietnamese rivals with a clear message: "step up your game, or step out of the game" when the new foreign-owned entity committed to bring Japanesequality service to the local market, by the guarantee of less than a 0.01-liter margin of error. Such event has been embraced by both the public and industry experts who have been long waiting for a positive change in this highly protective sector. ${ }^{81}$

\footnotetext{
$75 \quad$ Forbes Vietnam (2017), 'A FDI enterprise in petrol retail and distribution', 8 October 2017, retrieved from http://forbesvietnam.com.vn/tin-cap-nhat/thi-truong-ban-le-xang-dau-vietnam-xuat-hien-doanh-nghiep-ngoai-1372.html [accessed 22 June 2019].

76 Cong Thuong Newspaper (2017) (n 24).

77 Decision No.1855/QD-TTg of the Prime Minister on Approving Vietnam's National Energy Development Strategy up to 2020, with the outlook to 2050 (2007), Art.1.2, subs.b-Specific Objectives, para.4.

78 Thanh Nien Newspaper (2018), 'NSRP sold out the first batch of 5,000 m3 of RON 92 gasoline', 1 May 2018, retrieved from https://thanhnien.vn/tai-chinh-kinh-doanh/nha-may-loc-hoa-daunghi-son-xuat-5000-m3-xang-ron-92-dau-tien-958300.html [accessed 22 June 2019].

79 Dan Tri Newspaper (2017), 'Wrongful negotiation in Nghi Son Refinery - How compensating the loss?', 16 May 2017, retrieved from http://dantri.com.vn/kinh-doanh/dam-phan-ho-locdau-nghi-son-lay-tien-dau-de-bu-lo-20170516155004755.htm [accessed 22 June 2019]. Forbes Vietnam (n 74)

Tuoitre Newspaper (2017), 'Vietnam's fuel fight heats up as market welcomes first foreign player', 12 October 2017, retrieved from https://tuoitrenews.vn/news/society/20171012/vietnams-fuelfight-heats-up-as-market-welcomes-first-foreign-player/42018.html [accessed 22 June 2019]
} 
Although the appearance of a foreign competitor in petrol retail market was an interesting and a novel phenomenon for most, an overhaul of Vietnam's fuel policies is needed to change in competitiveness in this market. Firstly, the fully foreign-owned enterprise, Idemitsu Q8 Petroleum, is obliged to comply with regulations as the same as the domestic businesses. Particularly, the Decree No. 83/2014/ND-CP dated 3 September 2014 of Government ("Decree 83") provided the conditions applicable to all of petrol distribution units. Given that the petrol distribution is a conditional business line, prior to being granted the required license, the business entity has to fully satisfy the conditional precedents set forth in such regulations. For example, each distributor has to own or rent products import-export ports which are able for the access of minimum 7,000-tonne vessels, ${ }^{82}$ storage, ${ }^{83}$ outlet facilities, ${ }^{84}$ etc. Those requirements, even which could be justified on the ground of ensuring the products quality, protecting the consumers' interest, and other health-safety-environment issues, are significant barriers for market access for prospective businesses. ${ }^{85}$

While the Decree No. 08/2018/ND-CP (“Decree 08”) which partly amended some of articles of the Decree 83 may be seen as an expression of government's efforts to facilitate market access and competition, the petrol retail market remains to be a highly restricted market for foreign investors and businesses. Additionally, it is worth noting that while Vietnam has conferred exceptional privileges for numerous foreign companies in key energy projects that have importance for its national energy security interests, it is unlikely that Vietnam will open its petrol retail market to foreign entities pursuant to international arrangements, such as WTO, ${ }^{86}$ EVFTA, CPTPP. ${ }^{87}$

Secondly, the price of petrol and gasoline is intervened by the administrative decisions directly where the Ministry of Finance (MOF) and the Ministry of Industry and Trade jointly adjust the ceiling prices for the available products nationally. Even though the retailers are permitted to offer the price below the maximum, petroleum companies in Vietnam typically set their prices to match the ceiling. This is obviously a vicious circle. The strict regulations over gasoline prices force the businesses to fight for market share by increasing the discount to outlets, rather than offering competitive

\footnotetext{
The Decree 83, Art.7(2).

Ibid. Art.7(3).

Ibid., Art.7(4).

Tuoitre Newspaper (n 80).

Based on Vietnam's commitment to the World Trade Organization (WTO), "crude oil and petroleum products" are one of the 7 conditional business lines for which Vietnam is not obliged to open the market for foreign investors.

87 CafeF Newspaper (2017), 'The participation of Idemitsu Q8 Petroleum is the good signal for market', 7 October 2017, retrieved from http://cafef.vn/pho-tong-giam-doc-petrolimex-sutham-gia-cua-idemitsu-la-tin-hieu-tot-cho-thi-truong-nhung-chung-toi-da-chuan-bi-tuhang-chuc-nam-truoc-20171007005930684.chn [accessed 22 June 22, 2019].
} 
prices to customers. In turn, costs for businesses increase and prevent them from lowering retail prices. Furthermore, petroleum businesses are legally responsible for maintaining a fixed profit margin of VND300 per litre, which is already accounted for in the price customers pay at the pump. This not only guarantees that companies always remain profitable, but also narrows the room for competition among businesses. ${ }^{88}$

In this context, the controversial debate revolves around whether the State should deregulate provisions to set the ceiling prices of petrol products. On the one hand, those in favour of the deregulation policy put forward a persuasive argument whereby if a business could optimize the prices than those of its competitors, e.g. importing the lower price sources, it should be allowed to sell at more competitive prices. In other words, the State should let gasoline prices to be determined under the market rules and conditions, rather than the bureaucratic administrative intervention. Only then will there be the true competition among players, which will ultimately benefit to consumers. ${ }^{89}$

The opponents on the other hand come with a warning that any move towards deregulation should come with a caution in order to prevent foreign companies from manipulating Vietnam's fuel market. However, this opinion is flawed as the Institute for Pricing Research has shown that it is unlikely that the competition would result in "cutting-throat" business tactics. When foreigners enter the market, they can compete with local companies by relying on advanced management, effective retail system, and a diverse range of products. However, when it comes to gasoline, there is only a limited number of products that make it difficult to push the competitors out of the market. ${ }^{90}$

Thirdly, when one considers the market structure prior to the establishment of Idemitsu Q8, it can be seen that there were 31 domestic licensed importers and wholesalers, and around 120 retailers who controlled over 14,000 gas stations nationwide. Among others, Petrolimex can be deemed as the dominant undertaking/company, ${ }^{91}$ with the largest market share of nearly 50 percent followed by PVOil which enjoys over 20 percent market share. The remaining portion is shared by smaller competitors, such as Saigon Petro, Mipec Petro, Thalexim. ${ }^{92}$ There is apparently

\footnotetext{
$88 \quad$ Tuoitre News (n 80).

89 Ibid.

$90 \quad$ Ibid.

91 The Law on Competition (2004), Art.11 - Enterprises and groups of enterprises in dominant market position: "1. An enterprise shall be deemed to be in a dominant market position if such enterprise has a market share of thirty (30) percent or more in the relevant market or is capable of substantially restraining competition."

92 Cafebiz Newspaper (2017), 'Competition between Petrolimex and PVOil' (So găng Petrolimex và PV Oil: Hai đại gia ngành xăng đâu chuẩn bị ra mắt thị trường chứng khoán), 29 March 2017, retrieved from http://cafebiz.vn/so-gang-petrolimex-va-pv-oil-hai-dai-gia-nganh-xang-dauchuan-bi-ra-mat-thi-truong-chung-khoan-20170329095123871.chn [accessed 22 June 2019].
} 
a oligopolistic market ${ }^{93}$ dominated by a small number of suppliers that requires each company to take into account its rivals' actions and potential subsequent responses to its actions. ${ }^{94}$ The dilemma of distributors to keep the prices to match the ceiling amount or decrease them to compete with others is the current status of petrol retail market in Vietnam.

In practice, detecting a sub-competitive performance in oligopolistic market can be challenging, and the manner in which such phenomenon occurs, e.g. an explicit agreement among firms to restrain the competition, may be frustratingly difficult to investigate and remedy under competition and/or anti-trust law. ${ }^{95}$ For example, in the case of anti-competitive behaviour of Vinapco, the exclusive supplier for jet fuel had entered into a purchase agreement with Pacific Airlines (PA) to supply fuel for PA's planes, with the fuel price had been determined herein. ${ }^{96}$ Three months after the agreement, Vinapco invited PA to re-negotiate the new price. Although PA agreed that the increase of fuel price might be reasonable when taking into account the recent circumstance, it stressed that such increase has to be equal among domestic airline enterprises, particular PA and Vietnam Airlines (VNA). Because of the discriminative pricing imposed to it, PA complained in writing to Vinapco and sent the claim to the Vietnamese Competition Council. ${ }^{97}$

The ad-hoc Council considered jet fuel supply service in terms of supplying gasoline for civil aviation which is different than the service for other purposes, such as for military or household consumption. Thus, based on the characteristics and utility purposes of goods or services, the relevant market was determined and as such Vinapco occupied a dominant position therein. Consequently, Vinapco's behaviour was prohibited under Articles 13(4), 14(2) and 14(3) of the 2004 Competition Law which prohibits the abuse of market dominant position to damage the consumers' interest. Therefore, the fine of VND3.4 billion, combined with the legal fees, was issued against Vinapco. Vinapco appealed the decision however, the

93 "The primary idea behind an oligopolistic market (an oligopoly) is that few companies rule over many in a particular market or industry, offering similar goods and services. Because of a limited number of players in an oligopolistic market, competition is limited, allowing every firm to operate successfully." See, Corporate Finance Institute, 'What is an Oligopolistic Market or Oligopoly?', retrieved from https://corporatefinanceinstitute.com/resources/knowledge/economics/oligopolistic-marketoligopoly/ [accessed 21 June 2019].

94 Committee on Competition Law and Policy (1999), 'Oligopoly', Policy Roundtables DAFFE/ CLP(99)25, OECD, p.18, retrieved from https://www.oecd.org/daf/competition/1920526.pdf [accessed 22 June 2019].

95 OECD (2019), Oligopoly markets, retrieved from http://www.oecd.org/daf/competition/ oligopoly-markets.htm [accessed 22 June 2019].

96 The Purchase Agreement No. JET A-1 No. 34/PA2008 (2007).

97 Vietnam Competition Council (VCC) (2019), Case of abuse of market dominance, retrieved from http://www.hoidongcanhtranh.gov.vn/default.aspx?page=news\&do=detail\&category_ $\mathrm{id}=1$ \&id=97 [accessed 22 June 2019]. 
Supreme Court (Chamber of Appeal) upheld the initial judgment. ${ }^{98}$

Despite of this exemplary case, which reveals the genuine willingness of the authorities to counter anti-competitive practices, the competition among petrol distributors continues to be suspicious, particularly in the oligopolistic market with the strong protection and administrative intervention from the State.

Moreover, private sector participation in the SOEs equitisation is a motivation for fostering the needs of corporate transparency and efficiency. In the current status of petrol retail market, there is currently merely a race between two giants, namely Petrolimex and PVOil (PVN's subsidiary).

The former was established in 1956, with core business is comprised of petrol import-export and production. Besides trading petroleum products, Petrolimex also provides other goods and services, such as telecommunications, civil engineering consultancy, transport, real estate and car repair, invests in insurance companies and commercial banks (e.g. holding 40 percent of stake in PG Bank). It owns the largest petrol distribution system, around 2,400 outlets which occupy 44 percent of the domestic oil market, with over 50 percent being directly sold to consumers, around 20 percent directly sold to industrial customers. ${ }^{99}$ The State, by proceeding with the plan of 2016-2020 SOEs equitisation, has sold 8 percent of Petrolimex stake to JX Nippon Oil \& Energy (JX NOE) following nearly two years of negotiations, with the deal value around JPY 20 billion (US $\$ 183$ million out of Petrolimex's valuation at US $\$ 1.77$ billion). It is expected that this firm could optimise its operation system, including the management of the petrol station network and payment method. ${ }^{100}$

The latter company, PVOil, was formed by the merger of Petroleum Trading Corporation (Petechim) and Petroleum Products Processing and Distribution Company (PDC) in 2008 and is the sole unit of PVN in charge of crude oil import-export, trading and processing, condensate and bio-fuel production. ${ }^{101}$ In spite of being a new comer to the energy retail market, it has been eager to expand its market share, set a chain of outlets and acquire smaller rival companies. Consequently, its distribution system has increased to approximately 540 filling stations, amounting to over 20 percent of the market

\footnotetext{
98 Decision No. 11/QD-HDXL of Vietnam Competition Council regarding Vietnam Air Petrol One Member Co., Ltd. stopped supplying gasoline for Jetstar Pacific Airlines (2009).

$99 \quad$ Vietnam Investment Review (2017), 'Foreign investors gunning for petroleum retail market', 13 July 2017, retrieved from http://www.vir.com.vn/foreign-investors-gunning-for-petroleumretail-market-50575.html [accessed 22 June 2019].

100 The Voice of Vietnam (VOV) (2016), 'Why do Japanese want a stake in Petrolimex?', 13 March 2016, retrieved from http://english.vov.vn/trade/why-do-japanese-want-a-stake-inpetrolimex-314531.vov [accessed 22 June 2019].

101 Decision No. 1250/QD-DKVN of PVN Board of Directors (2008).
} 
share within a few years of being in operation. ${ }^{102}$ With the monies gained from the equitisation, PVOil has been enthusiastic to upgrade its market share given that its biggest rival shall be restricted under the current competition law provisions. In relation to the prohibited cases of economic concentration, Article 14 of the Vietnamese Competition Law 2014 states that:

"Any economic concentration shall be prohibited if the enterprises participating in the economic concentration have a combined market share in the relevant market of more than fifty (50) percent, except in the cases stipulated in article 19 of this Law or where the enterprise after the economic concentration still falls within the category of medium and small sized enterprises as stipulated by law."

With the legal protection behind it, pursuant to its ambitious strategy for 2018 - 2022, PVOil plans to open 1,050 filling stations to increase the market share from 22 to 35 percent. ${ }^{103}$

Besides its strategy for expansion domestically, PVOil has sent offers to potential international investors, such as Shell, Idemitsu Kosan Co., Ltd, Kuwait Petroleum International (KPI), Puma (Swiss), SK (Korea), to sell its major stake, and reduce the State's ownership to 49 percent. ${ }^{104}$ However, such offers come with many conditions attached, including the guarantee of financial capacity, the experience in petroleum field globally, the commitment to hold the stake for at least 10 years, advanced technology transfer as well as honouring the obligation to purchase all Dung Quat refinery's petrol products. ${ }^{105}$ These preconditions are likely to reduce the attractiveness investment in PVOil by its foreign strategic partners.

Apart from boosting competition, the SOEs equitisation has urged the improvement of corporate governance practices, i.e. the transparency and economic-driven consideration in decision making. Information disclosure is one of the most important requirements in business processes however, availability and access legal and business information (e.g. company accounts and performance) stills remain as a major obstacle for foreign investors. ${ }^{106}$ For example, Vietnamese law (Decree No. 81/2015/ND-CP) requires that by the 31 May, PVOil shall publish its 6-monthly report for the previous year,

102 PVOil, 'Retail system', retrieved from https://www.pvoil.com.vn/mang-luoi/he-thong-cuahang-xang-dau [accessed 22 June 2019].

103 CafeF Newspaper, 'PVOIl will take 35 percent of petrol retail market share?',12 January 2018, retrieved from http://cafef.vn/pv-oil-lay-nong-thon-vay-thanh-thi-de-lay-35-thi-phan-banle-xang-dau-20180111174434895.chn [accessed 22 June 2019].

$104 \quad$ Ibid

105 PVOil (2018), 'Announcement: PVOil's delay for selecting strategic investors', 28 June 2018, retrieved from https://www.pvoil.com.vn/thong-bao-pvoil-tam-hoan-qua-trinh-lua-chon-nha-dau-tu-chienluoc [accessed 22 June 2019].

106 Customs Newspaper (2017), 'Equitization of state-owned enterprises: Narrow door for foreign strategic investors', 21 November 2017, retrieved from http://customsnews.vn/equitization-of-state-ownedenterprises-narrow-door-for-foreign-strategic-investors-5202.html [accessed 22 June 2019]. 
and by the $15^{\text {th }}$ of August, it is supposed to publish the 6-monthly report. ${ }^{107}$ However, PVOil rarely publishes its reports on time on the national portal http://business.gov.vn/ for public's perusal.

In contrast to the international practices which require large mergers and acquisitions deals to be subjected to due diligence and risk assessment, very few Vietnamese SOEs are aware of the importance of careful and detailed appraisal in the search for strategic shareholders. For instance, the criteria for selecting the strategic shareholders are not published publicly, or such documents are not written in English which makes it difficult for international investors to engage in such processes. ${ }^{108}$

In addition, there have been queries pertaining to how the procurement of SOE projects are conducted and if there are practices to hide collusions between project owners and contractors. ${ }^{109}$ Following the Bidding Journal's statistics, since 2009 PVOil had issued invitations to bid of 139 packages whereas the published result of selecting competent contractors was only 20 which contradicts the provisions of annual report of the projects financed by the State budget. ${ }^{110}$ Furthermore, there is evidence in number of instances that the prices quoted by contractors were coincidentally matched to the estimated project budget. For example, in the package of software licensing for 2016 - 2020, the quotation of CMC System Integrated Saigon was VND36.3 billion, compared to the pre-estimated budget of VND37.3 billion. In another case involving E5/E10 fuel blending system in Can Tho storage, Tan Long Technical Solutions was awarded, with the VND2.95billion bid as similar to the budget estimation. ${ }^{111}$

PVOil had also opted for 'negotiated bidding' which is applicable for some critical packages. For instance, PVC-MS (a subsidiary of PetroVietnam Construction Corp.) was selected to execute the package of constructing Nha Be Oil Storage, with the agreed amount of VND138.1 billion, compared to the approved budget of VND138.7 billion. Another case was the transportation of petrol products from Dung Quat Refinery to PVOil's storage system, the price of bid was VND218.8 billion while the estimated figure was around VND220

107 Decree No. 81/2015/ND-CP of Government on publishing of SOE' information (2015), Art.18 Publishing of corporate financial information.

108 Customs Newspaper (n 105).

109 The collusion in bidding is prohibited by the 2005 Law on Competition, Art.8.8: "Agreements in restraint of competition shall comprise collusion in order for one or more parties to win a tender for supply of goods and services" and Art.9.1: "The agreements stipulated in clauses 8 of Article 8 of this Law shall be prohibited." Also, the Bidding Law 2005 also stated in Art.12.3 "Prohibited acts in bidding include collusion or connivance between bid solicitors and contractors, between state management agencies, bid solicitors and contractors to alter bids or collusion with appraising or inspecting agencies, which affects the collective or national interests."

110 Circular No. 06/2017/TT-BKHDT of The Ministry of Planning and Investment (2017), Art.6 \& Art.7

111 Bidding Journal (2017), 'Lack of transparency in PVOil's bids', 21 March 2017, retrieved from http://baodauthau.vn/tai-chinh/mu-mit-thong-tin-nhu-pv-oil-36029.html [accessed 22 June 2019]. 
billion. ${ }^{112}$ These facts reveal that such bidding processes and practices could not adhere to the principles of competition, fairness and transparency, safeguard the objectives of the project and failed to enhance the competitiveness and effectiveness of subsequent project implementation. ${ }^{113}$

When becoming a listed public company, investors expect that PVOil has to conduct its business with diligence, under the supervision of shareholders and other institutional bodies, in accordance with the law on enterprises, ${ }^{114}$ and law on securities. ${ }^{115}$ In the next section, some major recommendations would be drawn to enhance the merits of privatisation in energy SOEs as well as to ensure the benefits to the stakeholders.

\section{Challenges and recommendations}

While progress has been made and ambitious new targets have been set, a number of barriers still exist for unleashing the full benefits of SOE reform. Firstly, many remaining SOEs are very large yet they achieved limited progress on resolving their complex ownership and management structures. Similarly, there has been limited progress in clarifying their financial and debt obligations. These shortcomings, coupled with the challenges related to SOE transparency and corporate governance, have made it more difficult to find strategic investors willing to participate in their IPOs. ${ }^{116}$

Secondly, the reform plan shall be continuously pursued with a view of selling the minority non-controlling stakes in these companies while the government still remains as the largest shareholder. The lesson learnt from the third wave of equitisation by the end of 2011 was that in spite of more than 20 years of reform and the equitisation of thousands of SOEs, only an estimated 30 percent of state ownership in corporate entities had been transferred to private sectors, and the government retained an average ownership stake of 57 percent in these firms. By only retaining minority control and decisionmaking authority, private sector strategic partners have had a limited ability and power to reshape these companies into globally competitive enterprises. ${ }^{117}$

Thirdly, while state ownership has shrunk in commercial sectors of the economy, government plans have continued to emphasize the importance

$112 \quad$ Ibid.

113 Vietnam Competition Agency (2014), Report: Review of Competition related regulations in sectoral regulatory laws, p.59.

114 The Law on Enterprises No. 68/2014/QH13 (2014), Art.171 - Information Publishing of Public Company)

115 The Law on Securities (consolidated version No. 27/VBHN-VPQH) (2018), Art.101 - Information Publishing of Public Company.

116 Asian Development Bank (2015), State-Owned Enterprise Reform in Vietnam: Lessons Learnt and Future Directions, Vietnam Public Finance Partnership Group High Level Meeting's background paper (July 2015), pp.3-4, retrieved from http://www.mof.gov.vn/webcenter/ShowProperty?nodeId=/ UCM56/MOF149448//idcPrimaryFile\&revision=latestreleased\&rid=1 [accessed 22 June 2019]. Ibid., p.4. 
of retaining control over many "strategic sectors" which are prone to natural monopolies and oligopolies, so in many cases a continued government role may be necessary. However, while SOEs have been partially equitised, the strict commercial terms with management independence, profit orientation, hard budget constraints, and accountability for KPIs and results could enhance the corporate performance. These characteristics are essential for improvement of SOEs performance as they force SOEs to meet their costs of capital and divest any activities that are not commercially viable. More importantly, improving SOEs performance in these sectors will rely not just on partial equitisation but on overhauling the government's competition policies, regulatory oversight and corporate governance standards in order to lift accountability for results. Unfortunately, what one can observe is that progress on this front has been slow. ${ }^{118}$

With reference to the subject matter above, the question of what the relationship between privatisation process (including opening market for non-State sectors, and divestment of SOEs) and competition policy to enhance the economic efficiency in the current Vietnam government's policy mix remains to be answered. In the Vietnamese context, it is clear that the nature of this relationship will mostly depend on the government's ultimate objective and choice. A rent-seeking government that wants to extract rent from businesses chooses not to privatise profitable SOEs and, moreover, promotes institutional arrangements that put excessive costs on private firms. In contrast, a market-friendly government chooses to privatise all profitable SOEs completely. Finally, if the government is benevolent and cares about the well-being of consumers, a competition policy aimed at levelling the playing field among businesses regardless their ownership origins ought to be put in place. ${ }^{119}$

In a paper prepared for the Vietnam Public Finance Partnership Group High Level Meeting which based on the experiences of Vietnam over three decades, it was shown that SOE reform is often a contentious, complex task; the process entails multiple reforms to laws, institutions of government, fiscal and regulatory policies, and also case-by-case enterprise restructuring. ${ }^{120}$ A number of important lessons derived from the experiences of both the government and institutional partners for swift progress can be grouped into two broad priority areas:

The first priority is the need to increase the pace and the depth of equitisation of SOEs engaged in commercial activities. Indeed, there remains a significant amount of SOEs doing business in unessential sectors where

\begin{tabular}{ll}
\hline 118 & Ibid. \\
119 & Vu, T.T.A. (n 22) \\
120 & ADB (n 115), p.6
\end{tabular}


private competition would lead to more efficient production. Subsequently, these could create serious distortions in Vietnam's economy, acting as a drag on economic growth and employment creation. Therefore, reducing State ownership and allowing fully commercial, market-driven companies to emerge should be the central priority of SOEs equitisation. Besides, removing government ownership and control of these entities would cause significant productivity, this goal could be supported by strengthening the legal environment for SOEs. ${ }^{121}$

With an array of legislative reforms being implemented over the last two decades to address specific legal inadequacies, the frequency and diversity of legal revisions have contributed to a proliferation of new laws, decrees and guidelines. For example, the National Assembly has enacted a number of legal instruments relating to enterprises, such as the 2014 Enterprise Law, ${ }^{122}$ the 2014 Investment Law, ${ }^{123}$ the 2017 Law on Management and Use of State Assets. ${ }^{124}$ These contain important provisions, which serve as the foundation for the commercial markets and trade in general as well as the regulations of SOEs operations in order to meet the State regulatory requirements on enterprises, while improving the efficiency and competitiveness of businesses in their production, operations and restructuring.

In order to improve the legal system in support of the acceleration the SOE restructuring process, the Prime Minister have issued regulations and policies, including the Decree No. 81/2015/ND-CP on publishing SOE information which mandates the Ministry of Planning and Investment (MPI) to announce the list of enterprises violating such requirements via the portal http://business.gov.vn/, the Decision No. 35/2013/QD-TTg on Rules of Independent Auditors in SOEs owning 100 percent State capital, the Decision No. 58/2016/QD-TTg classifying three SOEs categories and the list of restructured SOEs in the $2016-2020$ period can also be added to the list of positive legislative initiatives undertaken by the Prime Minister.

Inadvertently, adherence to the SOE regulations has become increasingly complex which in turn may be hindering SOEs efforts to reform themselves as well as the private sectors ability to understand, and participate in prospective SOE equitisation. As a result, consolidation of the various legal instruments such as decrees, decisions, and resolutions that currently regulate SOEs and the equitisation procedures, and repealing any conflicting rules needs to be undertaken without a delay. ${ }^{125}$

The Law on Enterprises No. 68/2014/QH13 (2014).

The Law on Investment No. 67/2014/QH13 (2014).

The 2017 Law on Management and Use of State Assets No. 15/2017/QH14 (2017) which repealed the Law on Management and Use of State Assets No. 09/2008/QH12 (2008). 
In addition to fine-tuning the legal system, the government has endeavoured to build the specific institutions aimed to strengthen the unified management mechanism over SOEs and the coordination among its authorities. One of such efforts was the establishment of the National Steering Committee for SOE reform and development under the Prime Minister's Decision No. 2092/QD-TTg. ${ }^{126}$ The Committee is a part of the Cabinet Government, chaired by a Deputy Prime Minister and consists of senior officials from relevant ministries and government agencies. ${ }^{127}$

However, the efficiency of this mechanism is questionable because in some cases, the Committee has not been able to fully resolve the fragmentation of responsibility that currently exists in SOE reform process. Particularly, different ministries have drafted their own SOE-related regulations, with limited or no consultation with other relevant agencies. ${ }^{128}$ Moreover, the decision-making process is time consuming, requiring at least 12 procedural steps and taking an average of 17 months. Therefore, the role of this Committee needs to be re-considered or it needs to be supported by competent governmental departments, in order to ensure an oversight of the inter-ministerial coordination, communication as well as the preparation and implementation of SOE-related laws and regulations. ${ }^{129}$

In fact, the report of MPI revealed that the recent model of State capital management has been a major factor behind insufficient supervision, lack of market-driven decision-making and economic efficiency and growth. The establishment of a highly concentrated entity, with the broad and comprehensive authority over SOEs, and employing sufficient team of skilled and experienced personnel has been critically important and necessary when taking into account the current circumstances. ${ }^{130}$ This necessity must have been foreseen as the recent entity, the Committee Commission for the Management of State Capital at Enterprises - CMSC was set up by the Resolution No. 09/NQ-CP ${ }^{131}$ and the Decree No. 131/2018/ND-CP (Decree 131). This entity shall be responsible for supervising and managing

126 Decision No. 2092/QD-TTg of Prime Minister (2011) which was a afterwards partly amended by the Decision No. 1039/QD-TTg (2016).

127 Decision No. 1039/QD-TTg of Prime Minister (2016), Art.1.

128 For example, the Ministry of Industry and Trade (MOIT) is solely mandated to coordinate with PVN to resolve the consequences of inefficient energy projects, such as PVTex's Ding $\mathrm{Vu}$ fibre plant, 3 bio-ethanol plants, and Dung Quat Shipyard, retrieved from http://www. moit.gov.vn/tin-chi-tiet/-/chi-tiet/tap-\%C4\%91oan-dau-khi-viet-nam-tap-trung-xu-lydut-\%C4\%91iem-cac-du-an-chua-hieu-qua-6301-16.html [accessed 22 June 2019].

$129 \quad \operatorname{ADB}(\mathrm{n} 115)$, p.6.

130 Bao Chinh Phu (the Government's Portal) (2018), 'The "Super" Committee and the role in State Capital Management', 20 September 2018, retrieved from http://baochinhphu.vn/Kinhte/Sieu-Uy-ban-va-vai-tro-quyet-dinh-trong-nang-tam-quan-tri-von-nha-nuoc/347191. vgp [accessed 22 June 2019].

131 The Resolution No. 09/NQ-CP of Government on establishing the Committee managing the State capital in enterprises (2018). 
the State capital in 7 economic groups, and 12 general corporations with a value of over VND5 quadrillion. ${ }^{132}$

The question is that whether the new Committee shall be competent enough to supervise a large number of SOEs doing business in very different lines of businesses and highly specialised sectors remains to be seen. Firstly, there is a concern on the human resources because apart from the board of management directly assigned by the Prime Minister, the number of staffs in 2018 shall be around 50, including personnel transferred from the relevant Ministries and the State Capital Investment Corporation (SCIC). Unlike the corporations who could employ the most competent personnel with negotiable benefits, the Committee - a governmental authority - has to follow the civil service recruitment procedures and can only offer the table/ level of salary under the 2008 Law on Cadres and Civil Servants. ${ }^{133}$ Salaries available are well below the amounts available in comparable companies in the private sector. Thus, such factors are likely to hinder the efforts to recruit experts with international experience in this field.

On the other hand, there is a valid concern that the newly established body would complicate the overlaps of competence and inconsistent practices among governmental agencies, because the State management over those sectors will not be eliminated. On the contrary, business registration system, tax regime, and SOE business management and governance will continue to follow the existing framework. Moreover, the spending of State budget would expand in line with the scale of the new Committee. ${ }^{134}$

The success of a sovereign fund investment - Temasek Holdings of Singapore - may be a valuable lesson for Vietnam. Most importantly, the clear separation between the Government's role as a policymaker and regulator and that of Temasek Holdings as a shareholder and commercial owner of companies has driven the steady growth of the investment giant and helped Singapore to thrive as a nation. ${ }^{135}$ This corporate entity is fully owned by the Ministry of Finance, but its commitment to meritocracy, commercial discipline and accountability among the Temasek portfolio companies helps these firms become regional and global champions. Indeed, such companies could compete freely in a globally competitive and customer-focused marketplace. It is unlike many SOEs around the world that are protected from competition and cushioned from corporate realities through subsidies. Some of these SOEs may also become instruments to achieve politically-driven agendas. ${ }^{136}$

The Decree No. 131/2018/ND-CP (2018), Art.9(2).

The Law on Cadres and Civil Servants No. 22/2008/QH12 (2008).

The Government's Portal (n 129).

Lee, Y.N. (2014), 'Temasek's success down to separation of its role from Govt's', Today

News, 23 December 2014, retrieved from https://www.todayonline.com/business/temasekssuccess-down-separation-its-role-govts [accessed 22 June 2019]. 
Returning to Vietnam, the good signal that the primary purpose of the new Committee is not to govern the daily operations of SOEs, but it shall focus on managing the State capital as shareholders exercise their rights under the enterprises laws and corporate charters. Thus, the important matter is not the establishment of the new entity. Rather, what is more essential is the structural organisation, and the procedure to facilitate corporate performance and to enhance the transparency, accountability and the supervision of people - the ultimate owners of the State assets. ${ }^{137}$

Another key question within the first recommendation is the possibility for foreign investors to further engage in the equitisation process. According to the report of the State Securities Commission by the end of previous equitisation plan, the participation rate of foreign investors was only 9.5 percent, well below the target of 16.7 percent. Additionally, a report of the CIEM has shown that among the 46 corporations named for acquisition under the approved plan for the $2011-2016$ period, only 4 of them sold their shares to foreign strategic investors, accounting for only 8.7 percent. ${ }^{138}$ Against this backdrop, it can be concluded that the small scale of proportion of shares sold to strategic investors is one of the main reasons why SOEs equitisation becomes less attractive. Despite of the new and enabling legal provisions on the ownership ratio of foreign investors, the engagement of foreign investors is still controlled. For example, the Decree No. 60/2015/ND-CP (which amended the Decree No. 58/2012/ND-CP) guiding the 2010 Securities Law, provided that the maximum foreign ownership regarding the public companies operating in the conditional business lines can be up to 49 percent. ${ }^{139}$

This restrictions on the foreign ownership may be designed to create a barrier for the protection of young domestic industries. However, they result in a negative impact on attracting strategic foreign shareholders because by holding very small ownership ratio, foreign investors are unable to engage in the management of the company effectively and drive the company forward for positive changes and profits. There is no valid rationale for strategic investment and the potential for conflict of interest and oppression of other shareholders. ${ }^{140}$ Even if the ownership ratio could not be amended, strengthening the rights of minority shareholders could act as an important step in attracting more investors into SOEs' IPOs. For example, one practical measure which could be taken is amending the corporate charter of equitised

\footnotetext{
137 The Government's Portal (n 129)

138 Customs Newspaper (n 105).

139 The Decree No. 60/2015/ND-CP (2015), Art.2a, sub-article 1(b): Where a public company operates in the investment and business sector subject to conditions applied to foreign investors but none of specific regulations on the rate of foreign ownership, the maximum rate of foreign ownership will be $49 \%$.

140 Customs Newspaper (n 105).
} 
SOEs to allow strategic investors to hold a veto right on a predetermined set of issues, regardless of shareholding ratio. ${ }^{141}$

The second group of recommendations concentrates on improving the governance and performance of SOEs. Foremost, reducing the complexity and conflicting mandates of services delivered by SOEs is critically important. In order to improve their commercial performance, SOEs need to have clear market driven objectives and the same commercial discipline imposed on private corporations. Any non-commercial services which they are required to deliver but cannot be done on a fully commercial basis should be clearly mandated and publicly disclosed. ${ }^{142}$

For example, given that the national oil company - PVN - is the meant to fulfil some political goals, ${ }^{143}$ the Decision No. 1749/QD-TTg on the Development of PVN Strategy Plan to 2025, with a vision forwards $2035,{ }^{144}$ and the Decision No. $12119 /$ QD-BCT ${ }^{145}$ of Ministry of Industry and Trade stated that during the progress of PVN restructuring, the role of this company shall focus on two essential functions:

1. The commercial activities with four pillars exploration and production, natural gas, electricity, and petroleum processing; and

2. Very limited non-commercial goals whereas the regulatory function shall be removed out of its key objectives. ${ }^{146}$

It goes without saying that the government ought to ensure financial integrity and enforcement of corporate governance requirements effectively by relevant law enforcement authorities. Although the Vietnamese Government has articulated a clear vision and policy on improving the governance of SOEs by legal reform, implementation of these new legal provisions has been uneven - particularly in regards to increased transparency and disclosure of enterprise finances and operations. For instance, there is a legal requirement for public disclosure of information related to SOE corporate performance, including on enterprise websites; ${ }^{147}$ however, there has been limited success as the results indicate that only 265 out of 622 SOEs complied with such provisions in $2017 .{ }^{148}$

\footnotetext{
$141 \quad \operatorname{ADB}(\mathrm{n} \mathrm{115)}, \mathrm{p} .6$.

142 Ibid., p.7.

143 The Decision No. 1855/QD-TTg (2007), Art. 1.2(a).

144 Decision No. 1749/QD-TTg (2015).

145 Decision No. $12119 /$ QD-BCT of MOIT approving the Restructuring Petroleum Industry Plan to 2020 (2015)

146 Decision No. 12119/QĐ-BCT of MOIT on Approval the Restructuring Petroleum Industry Plan to 2020, with a vision to 2030 (2015), Art. 1, I - Objectives and Orientation, 2(a) Overall Objectives.

147 Decree No. 81/2015/ND-CP (2015), Art.5; Decree No. 50/2016/ND-CP (2016), Art.6

148 Thoi bao Tai Chinh Vietnam (2018), 'Publicize the list of SOEs who have to publish information', 18 March 2018, retrieved from http://thoibaotaichinhvietnam.vn/pages/kinh-doanh/2018-03-18/ phan-lon-dnnn-chua-thuc-hien-cong-bo-thong-tin-day-du-55001.aspx [accessed 22 June 2019].
} 
Furthermore, although many SOE restructuring plans have been approved, there is little publicly available information about the processes by which these plans were developed and executed. This lack of information raises uncertainties for the private sector and civil society. Improved consultation and information disclosure would significantly improve investor confidence and public perceptions on and support for these schemes. To address this situation, the current process of reporting to parent ministries and the Ministry of Finance can be changed by establishing a streamlined mechanism whereby a single entity is in charge as the focal point to collect and publish SOEs disclosure on its portal publicly. ${ }^{149}$ This entity could easily be the newly established Committee as mentioned above.

Finally, enhancing corporate governance of SOEs is a key solution for attracting investment and realising a competitive market and increasing profit, productivity and quality. From a corporate governance perspective:

The management of a national oil company (NOC) has a major impact on how well oil producing countries translate potential wealth into sustainable development that benefits citizens. An effective NOC can generate stable financial returns to the state, national technical capability, and strong commitments on environment and society. Inversely, mismanaged NOC often exacerbate waste and corruption and deprive the country of valuable resources. ${ }^{150}$

Therefore, the adequate oversight and control exercised by the shareholders seem to be the primary importance in order to reduce information asymmetries and the potential for managerial rent-seeking. According to some, corporate governance of SOEs is typically sub-standard compared to parctices in non-State/private sectors. ${ }^{151}$ Unlike the business entities governed by the Law on Enterprises, the article of association and charter of PVN is governed by separate Government's Decree, particularly the Decree No. 149/2013/ ND-CP and supplementary MOIT's legal documents. ${ }^{152}$ Pursuant to these legal provisions, the MOIT and MOF shall jointly assign three independent auditors who are responsible for overseeing the legality, care and prudence of both board of directors and the CEO in regards to practicing the rights of shareholders and managing the business operation of PVN. ${ }^{153}$

Some of the recommendations focus on the Board of Directors (BODs) who should provide the management with a clearly stated mission related to resource development. In order to ensure that the missions are sound and well informed, those directors should be selected and appointed based

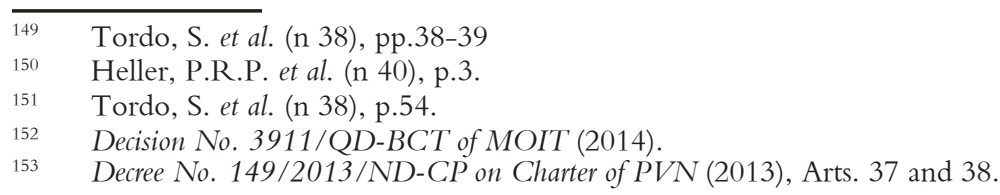


on their professional qualifications, experience and ability to ensure the owner's interests are well served, not based on their political affiliations. In addition, the CEO, instead being assigned by political organisations, should be recruited publicly, via competitive selection or hiring an experienced director from international oil companies. ${ }^{154}$

Aside from the BODs and CEO, both the Law on Enterprises and Decree No. 149/2013/ND-CP have emphasised the important role of the Board of Supervisors (BOSs) within the corporate structure. For example, the MOIT and MOF shall jointly assign three independent auditors who are responsible for overseeing the legality, care and prudence of both board of directors and the CEO in regards of practicing the rights of owner's representatives, managing the business operation of PVN. ${ }^{155}$

In short, recommendations can be clustered under two key areas: Firstly, the role of government in paving way to the investment ecosystem, including legal reforms and strengthening institutional coordination, incentivising and protecting the rights of investors during SOEs restructuring. Secondly, the requirements on accountability and performance of SOEs by applying internationally accepted, good governance practices.

\section{Conclusion}

This paper has critically analysed the frictions and concerns pertaining to the relationship between privatisation and competition in the Vietnamese oil and gas market since the initial determination by government to gradually build a free and fair sector in line with its strategic plan with the vision to $2050 .{ }^{156}$ The paper has identified a number of sectors specific examples whereby the acceleration of key energy SOEs' equitisation and facilitating market access, particularly in petrol retail market has been instigated.

While the optimum potential for investment and growth in this sector has not been achieved yet, the participation of a small number of foreignowned companies will at least provide a positive signal for competition whilst creating pressure on domestic petroleum distributors to upgrade their existing facilities and improve service and product quality. Moreover, inclusion of foreign stakeholders is likely to kindle the necessary SOEs' corporate governance reforms that meet the requirements of non-State investors, especially those of the foreign strategic partners.

Several recommendations that have been put forward come under two main themes: legal reform and corporate governance practices which in tandem would lead to a more competitive, efficient and profitable energy sector.

\footnotetext{
154 Cameron, P.D. \& Stanley, M. C. (2017), Oil, Gas and Mining - A Sourcebook for Understanding the Extractive Industries, The World Bank's the Extractive Industries Source Book (EISB), p.126.

155 Decree No. 149/2013/ND-CP on Charter of PVN (2013), Arts.37 and 38.

156 The Decision No.1855/QD-TTg (2007).
} 


\section{Reference \\ Working Papers/Reports}

[1] Allen \& Overy, Publications: Vietnam lifts the cap on foreign ownership of public companies (20 July 2015) http://www.allenovery.com/publications/en-gb/Pages/Vietnam-lifts-the-cap-onforeign-ownership-of-public-companies.aspx

[2] Asian Development Bank (ADB), State-Owned Enterprise Reform in Vietnam: Lessons Learnt and Future Directions, Vietnam Public Finance Partnership Group High Level Meeting's background paper (July 2015) http://www.mof.gov.vn/webcenter/ShowProperty?nodeId=/ UCM56/MOF149448//idcPrimaryFile\&revision=latestreleased\&rid=1

[3] Cameron, P.D. \& Stanley, M. C., Oil, Gas and Mining - A Sourcebook for Understanding the Extractive Industries, The World Bank's the Extractive Industries Source Book (EISB) (2017).

[4] Committee on Competition Law and Policy, Oligopoly, Policy Roundtables DAFFE/CLP(99)25, OECD (1999) https://www.oecd.org/daf/competition/1920526.pdf

[5] Heller, P.R.P., Mahdavi, P. \& Schreuder, J., Reforming National Oil Companies: Nine Recommendations, Natural Resource Governance Institute (July 2014) https:// resourcegovernance.org/sites/default/files/documents/nrgi_9recs_eng_v3.pdf

[6] Le, T.A.N. (2015) State-owned Enterprise Reforms in the TPP Negotiation: Is it a win-win for Vietnam?, RIETI Discussion Paper Series 15-E-092, https://www.rieti.go.jp/jp/publications/ dp/15e092.pdf

[7] OECD (2018) OECD Peer Reviews of Competition Law and Policy: Vietnam http://www. oecd.org/daf/competition/competition-law-and-policy-in-vietnam.htm

[8] Searle, S. \& Malins, C. (2016) Case study: refineries in Vietnam, The International Council on Clean Transportation (ICCT) Working Paper Vol.2016-3

[9] Singh, A., Competition and Competition Policy in Emerging Markets: International and Developmental Dimensions, UNCTAD G-24 Discussion Paper Series (No. 18, September 2002), http://unctad.org/en/docs/gdsmdpbg2418_en.pdf

[10] Tordo, S., Tracy, B.S, Arfaa, N., National Oil Companies and Value Creation, World Bank Working Paper No. 218 (2011)

[11] Tran, K.C. \& Djalal, D., The World Bank and Vietnam Work to Strengthen Fiscal Policies and Management Towards Sustainability, Efficiency, and Equity, Press Release (3 Oct 2017) http:// www.worldbank.org/en/news/press-release/2017/10/03/the-world-bank-and-vietnam-workto-strengthen-fiscal-policies-and-management-towards-sustainability-efficiency-and-equity

[12] Vietnam Competition Agency, Report: Review of Competition related regulations in sectoral regulatory laws (Hanoi, 2014)

[13] World Bank Group \& Vietnam Ministry of Planning and Investment, The 2035 Vietnam Report: Toward Prosperity, Creativity, Equity, and Democracy (2016)

\section{Journal articles}

[14] Le, H.H. (2017) Vietnam's New Wave of SOE Equitization: Drivers and Implications, ISEAS Perspective, Issue 2017, No. 57, https://www.iseas.edu.sg/images/pdf/ISEAS_Perspective_2017_57.pdf

[15] Ngoc Phuong, PetroVietnam: Focus on restructuring and boosting production, PetroVietnam Journal Vol. 6/2017 http://www.pvn.vn/DataStore/Documents/2017/Tapchi\%20Dau\%20khi/ TCDK\%2007\%202017.pdf

[16] Nguyen, H.T (2018) Enhanced oil recovery in Vietnam: Potential and Opportunities, PetroVietnam Journal Vol 6/2018, http://www.pvn.vn/DataStore/Documents/2018/ TapChiDauKhi/TCDK_6_2018.pdf

[17] Nguyen, V.T, Ogunlana, S.O. \& Dey, P.K. (2007) Risk management in oil and gas construction projects in Vietnam, International Journal of Energy Sector Management Vol. 1 Issue: 2 (pp.175194), p.176 https://doi.org/10.1108/17506220710761582

[18] Terlikowski P. et al., Modern financial models of nuclear power plants, Progress in Nuclear Energy, Vol 110 (January 2019).

[19] Vu, T.T.A. (2006) Competition and Privatisation in Vietnam: Substitutes or Complements?, Japanese National Graduate Institute for Policy Studies, Conference Papers (15 July 2006) http:// www.grips.ac.jp/vietnam/VDFTokyo/Doc/2ndConf15Jul06/2EcoSession2VTTAnh.pdf 